ISSN: 2162-3104 Print/ ISSN: 2166-3750 Online

Volume 8, Issue 2 (2018), pp. 659-676

(C) Journal of International Students

http://jistudents.org/

doi: $10.5281 /$ zenodo. 1250368

\title{
Positioning the Researcher in the Studies of International Student Identities
}

\author{
Jasper Kun-Ting Hsieh \\ The University of New South Wales, Australia
}

\begin{abstract}
Previous studies on international students have helped identify issues that explain these students' intercultural identities in relation to the learning in English-medium contexts. Scholarly attention has attached importance to the 'results' or the 'process' of the identity movements in the context of international education. Little attention has been paid to the conversations on the epistemology and theoretical framework that educational researchers have been using. This study is a response to Dervin's plea (2011) for a change for the qualitative studies on international students' interculturality. With a Post-structuralist Bourdieuian thinking, I demonstrated how analyzing and providing the researcher's positionality enhance the understanding towards the unspoken data and its analysis especially for the studies on international students' identities.
\end{abstract}

Keywords: identity studies, international students, positionality, validity

Much scholarly attention has been focusing on the identities of international students (ISs). The identities as international students in the English-speaking countries (or as most Chinese speakers would call, 'the West') and as returnees from the West are among the most popular roles for educational researchers. For the past two decades, identity studies on ISs are dichotomized into either result-based or process-focused.

From the 1990s to the first decade of the 2000s, ISs' identity studies focus on the identity results after the students entered into English-speaking 
context. Their studies were based on the ISs' learning experiences, English proficiency, intercultural communication competence and the cultural difficulties they encounter overseas (Angelova \& Riazantseva, 1996; Cross, 2006; Ladd \& Ruby, 1999; Lewthwaite, 1996; Lun, Fischer, \& Ward, 2010). In recent years, similar studies put emphasis on how external environments collide with the students' original identities and reshape these students' experiences overseas, revealing that identity movements have been recognized as being influenced by the external environment and gradually developed into personal identities (Brown \& Brown, 2013; Friedman, Liu, Chi, Hong, \& Sung, 2012; Gomes, 2015; Li \& Zhu, 2013; Rose-Redwood \& Rose-Redwood, 2013). While the effort might be moving attention away from the results to the causes of identity transformation, these studies inferred the causes from the examination of the identity results.

Moreover, these previous studies have acknowledged their participants' identities were reshaped by what they had experienced in an English-speaking and foreign context. These identities remain changeable. However, the identities that were acknowledged and studied were from certain stages of ISs' lives abroad, such as several months after they pursued higher education abroad. In other words, while the mutability of identity has been acknowledged, identities are being studied as the 'result' of mutation.

The other group of ISs' identity studies concentrates on the 'process' of identity transformation. This group believes that identities are multiple, complex and ongoing (Benton \& Craib, 2011; Ibarra \& Petriglieri, 2010). Therefore, the prolonged data collection and tighter engagement with the extended lives of the student participants after graduation are seen as ways to manifest the patterns (Gill, 2007), causal effects (Gill, 2010; Hao \& Welch, 2012) or the complexity (Gu \& Schweisfurth, 2015; Gu, Schweisfurth, \& Day, 2010) of ISs' identity transformation process. A refocus on the 'process' of identity mutation intends to bring out the depth of data to the existing scholarship. However, I share Dervin's concern (2011) over the lack of critical reflection on the data analysis in ISs' identity studies. In this autoethnographic study, I used two provocational stories as a vehicle to analyse and provide my researcher's positionality for the purpose of enhancing the criticality and credibility of the data analysis in relevant ISs' identity research. 


\section{LITERATURE REVIEW}

\section{A Plea to the Involvement of the Researcher's Reflexivity}

Dervin (2011) critically reviewed four qualitative studies on the issues related to ISs' interculturality. He discovered that the analyses of these studies remain at the surface of the discourse by accepting student participants' perceived utterances as the evidence for their intercultural transformation. Cultural contexts were treated in an objective and reified way. By changing the context, the English-speaking context would seemingly bring interculturality to ISs and acculturate their identities. In their studies, the notion of 'culture' was used uncritically and systematically in data interpretation, which inevitably trapped the educational researchers in an Othering game.

Having known that some result-based studies could be labelling ISs as the "reduced Other" (Grimshaw, 2007, p. 300), process-focused studies could be implicitly making those who do not study abroad as others. The host cultures were perceived as a static and superior objectivity which either made IS's culture of origin problematic and inferior or showed how much Westernised and superior when ISs became returnees. Like Dervin, Rizvi (2005) shows his concern over these cultural assumptions might circulate the Othering and leave the relational patterns between ISs and contexts behind.

Dervin's (2011, p. 47) "Janusian discourse", the notion borrowed from the image of the two-faced God, is critical about some ISs' identity studies would indicate the importance of focusing on the complexity and fluidity of identity changes across borders. However, the uncritical and nonreflexive data and analyses contribute to the findings that still stay within the spoken discourses. In order to go beyond the spoken and dig into the unspoken discourses, Dervin pleads for a more liquid approach for the studies on ISs' interculturality. In his suggestions, admitting the researchers' biases in data analysis through more researchers' reflexivity is extremely important.

Nonetheless, such suggestion is not easy to be put into practice for many academics. Dervin's plea is a change for how some educational researchers are analysing data for the studies on ISs' interculturality. This methodological change encourages to acknowledge the subjectivity of the researchers, which is something that a number of academics might feel 
uncomfortable with because "they want to keep doing things that the ways they've always done them" (Ellis \& Arthur, 2006, p. 442).

\section{Analysing and Providing Researcher's Positionality}

Positionality is defined as the researcher's gender, social status, educational and cultural backgrounds are the "marker of relational positions" (Maher \& Tetreault, 1993, p. 118). These relational positions can also be understood as the power positions between the researcher and the researched (LeCompte \& Schensul, 2010).

Based on this definition, ISs in previous studies were positioned and analysed under certain situations and engagements. For example, educational researchers locked down research participants' positionality when they were international students in the West (See, for example, Copland \& Garton, 2011; Halic, Greenberg, \& Paulus, 2009; Williams \& Johnson, 2011), or when they were in post-study lives (See, for example, Alberts \& Hazen, 2005; Cheung \& Xu, 2015; Gill, 2010; Hao \& Welch, 2012). However, it is rarely found that the researchers analyze and provide their positionality to the readers. The power relation between researchers and the participants seems to be either avoided or slightly touched.

This study believes that the researcher's reflexive practice of Autoethnography will be contributing to the effort for a more complete researcher's positionality especially when such positionality is in comparison with the researched. Autoethnography has been encouraged in the research of social sciences (Buckley, 2015; Starr, 2010) for its researchers moving away from being a distance and detached observer to an intimate participant (C. P. Ellis \& Arthur, 2006). As educational researchers, we all tend to choose the research topics that are related to our lives in the past, present and future. The decision of what and how to study is biased and subjective in the very first place. Researchers hold both the insiderness and outsiderness of their research topics (Maydell, 2010). The insiderness is from the fact that many researchers were/are either international students themselves or were/are teachers of international students. The outsiderness comes from the role as the research implementers who know the purposes and goals of conducting such studies.

Although we can find the criticisms against Autoethnography, such as its lack of connection to the studies of social (Delamont, 2007), and the unsettled arguments between evocative and analytical Autoethnography (See, for example, Anderson, 2006a, 2006b; Denzin, 2006; C. P. Ellis \& 
Arthur, 2006), Autoethnography is believed to be the methodology that provides unique access to the pivotal data (Vryan, 2006) and a more transparent perspective of data analysis for the readers.

Norman Denzin (2010) believes that qualitative inquiry is in the eighth moment where "social sciences and the humanities become sites for critical conversations about democracy, race, gender, class, nation-states, globalization, freedom, and community" (p. 13). The method of evaluating qualitative works in the eighth moment is moral and ethical, which requires authors to provide positionality, representational adequacy and critical viewpoints regarding their subjectivity before and after research. Denzin reminds us that qualitative researchers need to ponder over how they are positioned in their studies before and after the research. In this paper, I use my experience of analyzing and providing my positionality when I was conducting my Ph.D. research. In next section, I will use Bourdieuian theoretical framework to analyze my positionality. Then, I will demonstrate how I analyzed and provided my positionality when I had interaction with my research participants. All these efforts are for the purposes of making the qualitative inquiry as moral, participatory and collaborative as possible.

\section{Bourdieu's Notions of Capital, Habitus and Field}

Having known the methodological benefits of autoethngoraphy, Bourdieu's theoretical framework is introduced here for my later researcher's positionality analysis. Bourdieu's works target how social inequality has been reproduced and accepted ubiquitously. My background of becoming an international student in Australia involves class, globalization, freedom and community. When I, coming from an economic lower middle class, was pursuing academic power in Australian higher education, issues such as my localized idea of globalization, my perceived freedom in Taiwan and Australia and my relationship with Taiwanese and Australian communities, are issues that I need to analyse to help with understanding my positionality.

Bourdieuian thinking toolkit of capital, habitus and field has been widely cited in social sciences research (Cui, 2015; Davey, 2009, p. 276; Husu, 2013; Ihlen, 2007; Lin, 2012). However, it is less used in international students' identity study. The reason for the trilogy of capital, habitus and field to be widely applicable is because Bourdieu (2013) tried to transcend the dichotomous research on society (objectivity) and individuals (subjectivity) and used these three notions to understand how social 
inequality has been produced, reproduced and accepted ubiquitously. Bourdieuian thinking toolkit is an epistemology, a methodology and a theoretical framework (Thomson, 2008) which this study also believes that it gives researchers the flexibility to capture how international students' identities move in different social spaces and at different time points.

\section{Capital}

In The Forms of Capital, Bourdieu (1986) talks about three forms of capital: Economic, cultural, and social capital. These three forms of capital can be transferred, inherited, and accumulated (Dillon, 2014). One's wealth can be transferred into reputable education background. A business man's son can also be induced to necessary networks he needs for taking over his father business in the future. The linkage between economic and cultural capital is especially emphasized by Bourdieu. Well established educational resources can become the privilege for wealthy people. Through this viewpoint, it shows that educational institutes are important agency for the reproduction of social and cultural capital (Dillon, 2014; Moore, 2008).

Among three different forms of capital, cultural capital is tightly linked to education, which is what this study recommends for identity research under international education. It exists in the embodied (e.g. durable dispositions), objectified (e.g. books), and institutionalized (e.g. academic credentials) state (Bourdieu, 1986, p. 47). In international students' research, the academic form of cultural capital (henceforth, academic capital) deserves researchers' attention because the ultimate goal for international students to study abroad is for academic capital, a form of highly transferrable capital.

\section{Habitus and Field}

Bourdieu's habitus is his attempt to transcend the dualism of subjectivity and objectivity. The notion of habitus is Bourdieuian-framed identity. It is defined as people's subjectivity which is a continuous process of state of mind socially generated and written into our mind without knowing (Bourdieu, 1990a; Steph, 2014). Therefore, the formation of habitus is below the level of consciousness (Bourdieu, 1990b). It is "embodied history, internalized as second nature and so forgotten as history (Bourdieu, 1990b, p. 56)."

Bourdieu's notion of field needs to incorporate with habitus in order to understand the relational philosophy between an individual's internalized 
potentialities and the context which he/she acts in (Bourdieu, 1998). The structure of field is stratified, and one dominant field will generate many more subfields under it. The most important feature of field is its dynamic relation with how field members take, maintain or improve their positions (Moore, 2008). In each field, it has its own schemes of thoughts and logic of practice which need to be put in effect in order to make sure the sustainability of the field existence. When joining a field, one can expect the practice of doxa, the naturalization of arbitrariness (Bourdieu, 1977) from its field members.

\section{PROVOCATION AND POSITIONALITY}

\section{"Free your mind"}

I grew up in a small fishing village in northern Taiwan. Dad is a Hokkien fisherman and couldn't continue his education after the age of ten. Mum is a full-time house wife and needs to look after a big family of eight. Making a living for this big family is not an easy task. It leaves Dad no choice but to become a fisherman on overseas fishing vessels. He has survived storms and pirates' robberies. The best souvenir would always be the bedtime stories of what he saw this time at his return once for six months. My parents insisted on giving me all the English resources they could possibly have, such as, sending me to learn English and providing me with English learning resources with the money they had saved up.

With English proficiency than average Taiwanese students, I entered into a reputable university, and then my academic career followed by graduation. Without realising how fast time flies, I had left my fishing village for 15 years. With my job as an English teacher in tertiary education, I was able to afford a better house in the urban area of Taipei for my family. I persuaded them to sell the house and moved to the city with me. Eventually, they did what I had been asking for. Although the old small timber and brick house in the fishing village is no longer ours, Dad bought a small fishing boat with his pension and docked it at the old quay. He came back sometimes and enjoyed his last piece of reminisce as a fisherman with the boat.

Years after being an English teacher, I had been telling my parents about how unhappy I found myself in teaching textbooks and doing quantitative research. I simply couldn't convince myself I was doing something meaningful. After experiencing and knowing the possibility of 
becoming a qualitative researcher in Australia, I made up my mind to give up scholarship for my quantitative research proposal in the UK and became a self-funded student in Australia. I would always remember the morning when Dad gave me an envelope in which there was money from selling his boat for my first semester's tuition fee after I told them to forgive my selfishness for putting everyone back to financial difficulties again. Dad told me exactly what Mum had told me before, "Go and free your mind".

\section{Analyzing my Positionality}

In my story, the reason for my parents' many sacrifices for my education in the inner Taipei City is because economic capital owners tend to congregate more educational resources in urban school boroughs, such as experienced teachers, more systematic school management and diverse educational courses in many more areas. An educational institute in the resourceful Taipei City was considered a useful agency to help me accumulate more other forms of capital in hopes of making my future life better than theirs.

Anchoring the notion of capital with habitus and field, academic capital is the major contributor for my latter identity movements. Academic capital, the institutionalized form of cultural capital (Moore, 2008), constructed who I was as a university lecturer teaching English in Taipei. Through my parents' economic sacrifices, I received quality education in the inner Taipei City for more than 10 years. During this decade-long of dwelling in the academic field where I was able to continue my higher education in English with other field members who are mostly from upper middle class. My habitus was added with another layer of meaning after acquiring academic capital and joining this field. I was considered as one of the members of this English-speaking field because of the academic capital I had by excelling others in many academic exams. Gradually, the ways how other field members, who hold the same academic capital, thought and acted infused into my logic, or as Bourdieu called "mimesis" (Bourdieu, 1990b, p. 73). My insistence on selling the house in the fishing village and moving to Taipei City was from the value system shared by academic field members. I was convinced that my parents could receive good medical care and material life in the urban area. Despite my background of economically lower middle class, the new field position, descent economic income and the new layer of habitus brought me this logic of association (Bourdieu, 1984, p. 36). I 
unconsciously chose to live the same lifestyle as my academic friends in the city in order to avoid being ousted because of my different choice of living.

The causal effect is as following: the accumulation of academic capital from reputable educational agencies requires time and commitment (Dillon, 2014). The more committed the individual is, the more likely his/her habitus will be different during and after the acquisition of academic capital. The habitus changes are in compliance with those other field members who hold similar capital in order to fit in his/her field position. Bourdieu is correct about the value of capital an individual has decides the height of his/her position in the field. Academic capital brings the owner the distinctiveness and the profits (Bourdieu, 1986). However, we also need to realize that the new habitus will also be developed once the individual became the owner of this valuable capital in both the embodied/institutionalized state.

The logic of association happened in my teaching and researching career. My textbook-oriented teaching and quantitative-based researching were the selections out of the logic I possessed in the academic field. Majority of the members in Taiwan's English education field recognized that English teaching must be based on the authority (textbooks, dictionaries and native English speakers) and the research on English education must and can only be based on the hard science and numerical evidence. Regardless the struggles in my mind, this arbitrariness is deemed as the principles which every member is expected to abide by. Bourdieu called it the symbolic violence (Moore, 2008); however, I was unaware of this form of violence which others imposed on me as teaching native English and quantitative educational research were the principles that I internalized and integrated with my habitus gradually. It was also through this academic capital-turned habitus, we, those people with higher degree in Englishrelated disciplines, could maintain our exclusiveness in terms of employments and salaries because our group stands for the symbol of those Taiwanese who know how to speak English like native speakers. Through the acquisition of this academic capital, I modified my original habitus regarding what English is. It turned from a tool enabling me to know more about the world into a tool for profit-making and survival in Taiwan's academia.

With academic capital, I did exchange into higher economic capital which significantly overcome the economic dilemmas I inherited from previous generation. This deed further convinced me that I did become 
"free" (free your mind) as my parents wished for as I was free from significant debts and economically lower class. This was also the linkage that I believed the arbitrariness of this field could be the truth. Therefore, academic capital is more than an institutionalized state of cultural capital. It is the construction of habitus in the form of capital (Moore, 2008). When the teachers who finished higher education in the West congregate similar habitus and conduct the logic of selection, non-field members, namely those who are locally educated and good at English, but from non-English speaking educational backgrounds, are barred from entering this particular English education field and become teachers. My story of becoming an English teacher in Taiwan was my involvement in legitimizing the inequality for exclusive benefits with other field members through introducing and implementing certain rules, such as the academic capital from English-related majors at a reputable university, for entering the field. Acquiring and using the academic capital is the conduct of enacting field rules (Moore, 2008).

\section{"As long as you have money, you will be graduated eventually"}

It has been a year and a half since I left Taiwan. I am still getting used to how much I have changed in terms of how to do research. "Have I set my mind free yet?" I ask myself. A big step towards becoming more truthful to myself in research is to learn how to do my research with autoethnography. Sitting on the steps outside Hao-Yen's apartment building near Darling Harbour, I was reading Denzin's Interpretive Autoethnography (2014) . It looks pretty daunting because the involvement of the researcher's self is something I haven't heard other Ph.D. students talking about when discussing their research.

My thoughts are interrupted when I hear someone calling my name. It's Hao-Yen, walking towards me from his underground car park. I've made sure that I used body spray today, as he has commented at times that I smell like "walking pastry". While doing my Ph.D., I am also working as a part-time baker at a supermarket. He is right, I might smell like stale pastry after a long day of baking and another 30 minutes of biking to his place, especially in the summer heat like today. But I don't like body spray. It makes me smell like a different person. This is my first visit to his home, and I notice that the floor was just polished - I can see my reflection looking up at me. It's a little unnerving. Next, I notice that through the French window in the kitchen I can see part of Sydney's iconic city views. As we 
start talking, Hao-Yen discovers that I live in a tiny, single, windowless room, and I ride a cheap bicycle bought from my former Korean housemate. Wistfully shaking his head, seemingly in disbelief, he offers me a glass of wine and comments on my endurance. I am not sure how to receive his remark, but turn down the offer because I want to keep my head clear. Instead, he insists on giving me a glass of sparkling water.

Over the year, Hao-Yen is consistently negative in his comments about Australia and Australian education. He seems most critical that Australian higher degree education is profit-oriented, and the relationship between students and universities is that of a customer and service provider. Hao-Yen failed one required subject and is required to enrol for another semester. He smirked and said: "As long as you have money, you will be graduated eventually. What they [his university] want is more money."

\section{Providing my Positionality}

From Hao-Yen's and my own materialistic life quality, one of the obvious differences between us is economic capital, which already positioned us in different locations, despite living in the same city. My economic position influenced how I understood, interpreted, and now present Hao-Yen.

When doing autoethnography, one has to acknowledge the differences between me and my participants as international students in Sydney. The ethical crisis that I experienced with Hao-Yen was about a worry whether I was mired in the jealousy of his comfortable and taken-forgranted economic power. As Ellis (2009, p. 17) indicates, there is no solution for ethical crises due to the fact that there are always ongoing struggles inside an autoethnographer. However, it is my intention to acknowledge the potential viewpoints from some in an economically lower middle class. As the researcher of this autoethnography, I hold the accountability of providing a complex portrayal of my participants' identity movements (C. Ellis, 2009, p. 13). I need to acknowledge that my interpretations could be from the perspective of someone with an economically lower middle-class background. It is inevitable that my family, cultural and economic background influence how I interpret different participants, and also how readers see the world that I provide to them (Madison, 2012, p. 10). The shared insiderness, such as educational and cultural backgrounds, and the outsiderness, such as, in Hao-Yen's case, an individual from a different economic class, allow me to interpret both his 
spoken and unspoken statements. However, I also use Hao-Yen as an example to study the structure within middle class society where my participants are from.

Looking back, I wonder why I bothered using body spray just because Hao-Yen said that I smelled like "stale pastry". I usually spent some time with my participants straight after work. Once Hao-Yen told me about this, I would bring another clean T-shirt and body spray to make myself smell "normal" to fit in with "them". This is an indication that there was actually a gap between Hao-Yen's and my family of origin. In my later analysis, this little piece of triviality in my field notes showed me that I tried to cover up my lower economic class in front of him, which has led me to pay attention to his travel plans, his transportation, what he preferred to drink when I was around, and why he mentioned how I smelled. My feeling of economic inferiority in front of Hao-Yen and some other Taiwanese students is equal to exposing my vulnerability as a researcher. This selfawareness and acknowledgement of being a researcher with a higher educational background in contrast to my participants, but coming from a lower economic class, can prevent my research on identity movements from being trapped in personal emotion (Jones, Adams, \& Ellis, 2013).

\section{CONCLUSION}

As this is an autoethnographic discussion on the importance and necessity of analysing and providing the researcher's positionality before and after the study. I am using another prevocational vignette to conclude this paper. I dented the vignette in order to separate it from the conclusion.

It is 3 a.m. on the last day of February in 2013, and my flight is three hours away. I just finished packing and left lots of notes for my parents to remember how to pay their insurance fees, the mortgage and how to check if the money I transfer from overseas has arrived in their Taiwanese account. I left most of my savings, the house they live in, a car and a dog with them for my PhD studies in Australia. I sit on a chair in my room and look around at all the material goods I have earned from my various jobs over the past 8 years. Those teaching jobs I had in Taiwan gave me financial stability and brought the family out of debt, but they took away the passion I have for English and education. It's now 4:30 a.m. Mum comes into my room and invites me to have an early breakfast and burn the morning incense. This is a daily Buddhist ritual in my family, and we stick them into 
the small pot in front of the ancestors' spirit tablet and give our daily greeting to the ancestors. Mum has been doing this twice a day for as long as I can remember. When we are in the shrine room, dad is already there and holding three incense sticks. As their son, I must wait until my parents finish praying. They wish that our ancestors will give me strength to help me stay healthy and guide me to explore an unknown life in Australia. Although they say their wishes to a wooden tablet, I can, in a very direct way, feel how much they wish me to be happy and open-minded. I guess this is how my parents express their love to their children. They came from a harsh past where resources were scarce and making a living wasn't easy. Looking back at my childhood, I can't remember the last time they said 'I love you' to me, or hugged me. However, they will always make sure we are all well-fed, warm, and educated. I now realize that while I was chasing materialistic satisfaction and higher income, and thought that it was what they expected, they had always just wanted me to be happy and to be myself.

From result-based to process-focused studies, studies on ISs' identities are moving from breath to depth. While qualitative inquiry emphasizes the complexity of ISs' identity transformation throughout their overseas education, a growing concern over if the current fluidity of methodology can capture ISs' multi-directional identity movements. I used the researcher's positionality of my Ph.D. thesis to demonstrate how I unpacked the relationship between my research topic and I, as an international student, a former teacher and a supermarket baker from Taiwan. Then, I also showed how I incorporated my analyzed positionality with the interaction with one of my research participants. The positionality provided in this study is methodologically linked with the autoethographic reflexivity and theoretically analyzed with Bourdieuian notions of capital, habitus and field. This process of analyzing and then providing the researcher's positionality could help qualitative researchers go beyond the spoken data and into the unspoken materials that would lead to more critical and thought-provoking findings (Achebe, 1965).

\section{REFERENCES}

Achebe, C. (1973). The novelist as teacher. In G. Killam (Ed.). African writers on African writing (pp.1-4). London: Heinemann.

Alberts, H. C., \& Hazen, H. D. (2005). "There are always two voices...": International students' intentions to stay in the United States or return to 
their home countries. International Migration, 43(3), 131-154. doi: 10.1111/j.1468-2435.2005.00328.x.

Anderson, L. (2006a). Analytic autoethnography. Journal of Contemporary Ethnography, 35(4), 373-395. doi: 10.1177/0891241605280449.

Anderson, L. (2006b). On Apples, Oranges, and Autopsies: A Response to Commentators. Journal of Contemporary Ethnography, 35(4), 450-465. doi: $10.1177 / 0891241606287395$

Angelova, M., \& Riazantseva, A. (1996). "If you don't tell me, how can I know?": A case study of four international students learning to write the U.S. way. Written Communication, 16(4), 491-525.

Benton, T., \& Craib, I. (2011). Philosophy of social science: The philosophical foundations of social thought (2nd ed.). Hampshire, UK: Palgrave.

Bourdieu, P. (1977). Outline of the theory of practice (R. Nice, Trans.). Cambridge, UK: Cambridge University Press.

Bourdieu, P. (1984). Distinction: A social critique of the judgement of taste (R. Nice, Trans.). London: Routledge.

Bourdieu, P. (1986). The forms of capital. In J. E. Richardson (Ed.), Handbook of theory of research for the Sociology of Education (pp. 241-258). New York: Greenwood.

Bourdieu, P. (1990a). In other words: Essays towards a reflexive Sociology. Stanford, Calif: Stanford University Press.

Bourdieu, P. (1990b). The logic of practice. Cambridge, UK: Polity Press.

Bourdieu, P. (1998). Practical reason. Cambridge, UK: Polity Press.

Bourdieu, P. (2013). Symbolic capital and social classes. Journal of Classical Sociology, 13(2), 292-302.

Brown, J., \& Brown, L. (2013). The international student sojourn, identity conflict and threats to well-being. British Journal of Guidance \& Counselling, 41(4), 395-413. doi: 10.1080/03069885.2012.729026.

Buckley, R. (2015). Autoethnography helps analyse emotions. Frontiers in Psychology, 6, 1-3. doi: 10.3389/fpsyg.2015.00209.

Cheung, A. C. K., \& Xu, L. (2015). To return or not to return: Examining the return intentions of mainland Chinese students studying at elite universities in the United States. Studies in Higher Education, 40(9), 1605-1624. doi: 10.1080/03075079.2014.899337.

Copland, F., \& Garton, S. (2011).''I felt that I do live in the UK now.”: International students' self-reports of their English language speaking experiences on a pre-sessional programme. Language and Education, 25(3), 241-255. doi: 10.1080/09500782.2011.566617.

Cross, J. (2006). Engaging diversity at an Australian university: Chinese international students' perceptions of their social experience while studying in Australia. Paper presented at the EDU-COM 2006 International 
Conference. Engagement and Empowerment: New Opportunities for Growth in Higher Education, Edith Cowan University, Perth, Australia.

Cui, D. (2015). Capital, distinction, and racialized habitus: Immigrant youth in the educational field. Journal of Youth Studies. doi: 10.1080/13676261. 2015.102093.2

Davey, G. (2009). Using Bourdieu's concept of habitus to explore narratives of transition. European Educational Research Journal, 8(2), 276-284. doi: 10.2304/eerj.2009.8.2.276.

Delamont, S. (2007). Arguments against Auto-Ethnography. Qualitative Researcher, (4), 2-4.

Denzin, N. K. (2006). Analytic autoethnography, or déjà vu all over again. Journal of Contemporary Ethnography, 35(4), 419-429. doi: 10.1177/ 0891241606286985.

Denzin, N. K. (2010). The qualitative manifesto: A call to arms. Walnut Creek, CA: Left Coast Press.

Denzin, N. K. (2014). Interpretive autoethnography (2nd ed.). Thousand Oaks: Sage.

Dervin, F. (2011). A plea for change in research on intercultural discourses: A 'liquid' approach to the study of the acculturation of Chinese students. Journal of Multicultural Discourses, 6(1), 37-52. doi: 10.1080/17447143. 2010.532218

Dillon, M. (2014). Introduction to sociological theory: Theorists, concepts and their applicability to the twenty-first century (2nd ed.). West Sussex, UK: Wiley.

Ellis, C. (2009). Telling tales on neighbors: Ethics in two voices. International Review of Qualitative Research, 2(1), 3-28.

Ellis, C. P., \& Arthur, B. P. (2006). Analysing Analytical Autoethnography: An autopsy. Journal of Contemporary Ethnography, 35(5), 429-449. doi: 10.1177/0891241606286979.

Friedman, R., Liu, W., Chi, S. C. S., Hong, Y. Y., \& Sung, L. K. (2012). Crosscultural management and bicultural identity integration: When does experience abroad lead to appropriate cultural switching? International Journal of Intercultural Relations, 36(1), 130-139. doi: 10.1016/j.ijintrel. 2011.03.002.

Gill, S. (2007). Overseas students' intercultural adaptation as intercultural learning: A transformative framework. Compare: A Journal of Comparative and International Education, 37(2), 167-183. doi: 10.1080/ 03057920601165512.

Gill, S. (2010). The homecoming: an investigation into the effect that studying overseas had on Chinese postgraduates' life and work on their return to China. Compare: A Journal of Comparative and International Education, 40(3), 359-376. doi: 10.1080/03057920903464555. 
Gomes, C. (2015). Negotiating everyday life in Australia: Unpacking the parallel society inhabited by Asian international students through their social networks and entertainment media use. Journal of Youth Studies, 18(4), 515-536. doi: 10.1080/13676261.2014.992316.

Grimshaw, T. (2007). Problematizing the construct of 'the Chinese learner': Insights from ethnographic research. Educational Studies, 33(3), 299-311. doi: $10.1080 / 03055690701425643$

Gu, Q., \& Schweisfurth, M. (2015). Transnational connections, competences and identities: Experiences of Chinese international students after their return 'home'. British Educational Research Journal, 47(6), 947-970. doi: 10.1002/berj. 3175

Gu, Q., Schweisfurth, M., \& Day, C. (2010). Learning and growing in a 'foreign' context: Intercultural experiences of international students. Compare, 40(1), 7-23. doi: 10.1080/03057920903115983

Halic, O., Greenberg, K., \& Paulus, T. (2009). Language and academic identity: A study of the experiences of non-native English speaking international students. International Education, 38(2), 73-110.

Hao, J., \& Welch, A. (2012). A tale of sea turtles: Job-seeking experiences of hai gui (high-skilled returnees) in China. Higher Education Policy, 25, 243260. doi: $10.1057 /$ hep.2012.4.

Husu, H. M. (2013). Bourdieu and social movements: Considering identity movement in terms of field, capital and habitus. Social Movement Studies, 12(3), 264-279. doi: 10.1080/14742837.2012.704174.

Ibarra, H., \& Petriglieri, J. L. (2010). Identity work and play. Journal of Organizational Change Management, 23(1), 10-25. doi: 10.1108/ 09534811011017180.

Ihlen, Ø. (2007). Building on Bourdieu: A sociological grasp of public relations. Public Relations Review, 33, 269-274. doi: 10.1016/j.pubrev.2007.05.005.

Jones, S. H., Adams, T. E., \& Ellis, C. (2013). Coming to know autoethnography as more than a method. In S. H. Jones, T. E. Adams \& C. Ellis (Eds.), Handbook of autoethnography (pp. 17-47). Walnut Creek, CA: LC Press.

Ladd, P. D., \& Ruby, R. J. (1999). Learning style and adjustment issues of international students. Journal of Education for Business, 74(6), 363-367. doi: 10.1080/08832329909601712.

LeCompte, M. D., \& Schensul, J. J. (2010). Designing \& Conducting Ethnographic Research: An Introduction (2nd ed.). Lanham, Maryland: AltaMira Press.

Lewthwaite, M. (1996). A study of international students' perspectives on crosscultural adaptation. International Journal for the Advancement of Counselling, 19(2), 167-185. doi: 10.1007/BF00114787

Li, W., \& Zhu, H. (2013). Translanguaging identities and ideologies: Creating transnational space through flexible multilingual practices amongst 
Chinese university students in the UK. Applied Linguistics. doi: 10.1093/applin/amt022

Lin, J. (2012). Coming to belong: A narrative analysis of international students' experiences in an Australian university. (Doctor of Philosophy), Queensland University of Technology, Queensland, Australia.

Lun, V. M.-C., Fischer, R., \& Ward, C. (2010). Exploring cultural differences in critical thinking: Is it about my thinking style or the language I speak? Learning and Individual Differences, 20, 604-616. doi: 10.1016/j.lindif. 2010.07.001

Madison, S. (2012). Critical ethnography: Method, ethics, and performance (2nd ed.). Thousand Oaks: Sage Publications.

Maher, F. A., \& Tetreault, M. K. (1993). Frames of positionality: Constructing meaningful dialogues about gender and race. Anthropological Quarterly, 66(3), 118-126. doi: $10.2307 / 3317515$

Maydell, E. (2010). Methodological and analytical dilemmas in autoethnographic research. Journal of Research Practice, 6(1). Retrieved from http://jrp.icaap.org/index.php/jrp/article/view/223/190

Moore, R. (2008). Capital. In M. Grenfell (Ed.), Pierre Bourdieu: Key concepts (pp. 101-117). Stocksfield: Acumen.

Rizvi, F. (2005). International education and the production of cosmopolitan identities. Paper presented at the Transnational Seminar Series at the University of Illinois at Urbana-Champaign, Champaign, Illinois.

Rose-Redwood, C. R., \& Rose-Redwood, R. S. (2013). Self-segregation or global mixing?: Social interactions and the international student experience. Journal of College Student Development, 54(4), 413-429. doi: $10.1353 /$ csd. 2013.0062

Starr, L. J. (2010). The use of Autoethnography in educational research: Locating who we are in what we do. Canadian Journal for New Scholars in Education/ Revue canadienne des jeunes chercheures et chercheurs en éducation, 3(1), 1-9.

Steph, L. (2014). Identity: Sociological perspectives (2nd ed.). Cambridge: Policy Press.

Thomson, P. (2008). Field. In M. Grenfell (Ed.), Pierre Bourdieu: Key concepts (pp. 67-81). Stocksfield: Acumen.

Vryan, K. D. (2006). Expanding analytical autoethnography and enhancing its potential. Journal of Contemporary Ethnography, 35(4), 405-409. doi: $10.1177 / 0891241606286977$

Williams, C. T., \& Johnson, L. R. (2011). Why can't we be friends? Multicultural attitudes and friendships with international students. International Journal of Intercultural Relations, 35, 41-48. doi: 10.1016/j.ijintrel.2010.11.001 
Jasper Kun-Ting Hsieh holds a Ph.D. in Education. His research interests are International Education, TESOL and Sociology of Education. Email: rosshsieh@gmail.com

Manuscript submitted: September 20, 2016

Manuscript revised: December 6, 2016 Accepted for publication: December 20, 2016 